\title{
Design of Magnesia-Spinel Bricks for Improved Coating Adherence in Cement Rotary Kilns
}

\author{
Graziella Rajão Cota Pacheco ${ }^{1, *}$, Geraldo Eduardo Gonçalves ${ }^{1}$ and Vanessa de Freitas Cunha Lins ${ }^{2}$ (i) \\ 1 RHI Magnesita Research and Development Center, Contagem 32210-190, Brazil; \\ geraldo.eduardogoncalves@contractor.rhimagnesita.com \\ 2 Chemical Engineering Department, Universidade Federal de Minas Gerais, Belo Horizonte 31270-901, Brazil; \\ vlins@deq.ufmg.br \\ * Correspondence: graziella.pacheco@rhimagnesita.com
}

Citation: Pacheco, G.R.C.; Gonçalves, G.E.; Lins, V.d.F.C. Design of

Magnesia-Spinel Bricks for Improved Coating Adherence in Cement Rotary Kilns. Ceramics 2021, 4, 652-666. https://doi.org/10.3390/ ceramics4040046

Academic Editors: Narottam P. Bansal and Gilbert Fantozzi

Received: 1 April 2021

Accepted: 19 November 2021

Published: 29 November 2021

Publisher's Note: MDPI stays neutral with regard to jurisdictional claims in published maps and institutional affiliations.

Copyright: () 2021 by the authors. Licensee MDPI, Basel, Switzerland. This article is an open access article distributed under the terms and conditions of the Creative Commons Attribution (CC BY) license (https:// creativecommons.org/licenses/by/ $4.0 /)$.

\begin{abstract}
It is well known that doloma bricks present better coating adherence than magnesia-spinel bricks when applied in cement rotary kilns, which is related to the different coating formation mechanism. The coating has an essential role in prolonged operation by protecting the refractory lining; thus, it is important to improve its adherence on magnesia-spinel refractories. The objective of this investigation is to study different compositions of magnesia-spinel bricks, achieved by varying additives used (calcined alumina, limestone, hematite and zirconia) and firing temperature $\left(1500{ }^{\circ} \mathrm{C}\right.$ and $1700^{\circ} \mathrm{C}$ ), to enhance the coating adherence measured by the sandwich test. The results have pointed out that the use of higher firing temperature contributes positively to physical adherence due to well-sintered refractory structure and elevated permeability, attaining coating strength superior to $2 \mathrm{MPa}$. For the chemical adherence, the addition of $2 \mathrm{wt} . \%$ of limestone increased the coating strength to $3 \mathrm{MPa}$, but resulted in a drop in hot properties. In this context, the most suitable approach to improve adherence of clinker coating and maintain hot properties in suitable levels is to increase the firing temperature.
\end{abstract}

Keywords: magnesia-spinel refractory brick; coating; improvement

\section{Introduction}

Doloma and magnesia-spinel refractory bricks have increased their importance in cement rotary kilns since the hexavalent chrome issues associated with magnesia-chromite bricks became a major concern in the early 1980's [1-3]. Both refractories present high refractoriness and chemical compatibility to basic environments, what qualifies them for use in cement kilns. Despite the disadvantage of hydration presented by doloma bricks, the formation of a strongly adhered clinker coating onto these bricks is an important advantage when applied in the burning zone of cement rotary kilns [4]. The coating, which is a clinker layer adhered to the brick surface, has an important role in prolonged operation by protecting the refractory lining from chemical, thermal and abrasive wear, and reduced energy consumption in cement production $[1,4,5]$.

The better coating adherence presented by doloma bricks compared to magnesiaspinel bricks is related to the different coating formation mechanism. Doloma refractory provide a large amount of $\mathrm{CaO}$, which reacts with dicalcium silicate $\left(\mathrm{C}_{2} \mathrm{~S}\right)$ from clinker, leading to the formation of a tricalcium silicate $\left(C_{3} S\right)$ rich zone at the clinker-brick interface, with a strong bonding between the clinker and the brick $[1,2,5]$. Therefore, the coating formation on doloma bricks does not require any excessive liquid phase formation [6]. On the other hand, the liquid phase formation is inherent to the mechanism of coating adherence on magnesia-spinel bricks, since spinel reacts with lime phases from clinker to form low refractoriness phases, such as mayenite $\left(\mathrm{C}_{12} \mathrm{~A}_{7}\right)$ and $\mathrm{Q}$ phase $\left(\mathrm{Ca}_{20} \mathrm{Al}_{26} \mathrm{Mg}_{3} \mathrm{Si}_{3} \mathrm{O}_{68}\right)$. The resulting liquid phase intensifies the clinker-brick interaction, but only a thin layer of dicalcium silicate is formed, as tricalcium silicate cannot coexist with spinel $[3,5,6]$. 
Many authors have studied the coating adherence on basic bricks [7-12]. Recently, the sandwich coating test has been applied in some studies [2,3,6,11,12]. Guo et al. [3] showed that the most significant effects on adherence strength of magnesia-spinel bricks are silica ratio $\left(\mathrm{SR}=\mathrm{SiO}_{2} / \mathrm{Al}_{2} \mathrm{O}_{3}+\mathrm{Fe}_{2} \mathrm{O}_{3}\right.$ ) of the cement raw meal, heating rate of the sandwich test and particle size of the meal. Meng et al. [11] investigated the effect of zircon $\left(\mathrm{ZrO}_{2} \cdot \mathrm{SiO}_{2}\right)$ addition on coatability of $\mathrm{MgO}-\mathrm{C}_{2} \mathrm{~S}-\mathrm{C}_{3} \mathrm{~S}$ refractory materials. According to the study, the highest adherence strength was obtained for $0.5 \mathrm{wt} . \% \mathrm{ZrO}_{2}$ addition because the dissolution of $\mathrm{CaZrO}_{3}$ into the cement clinker increased the viscosity of the clinker and the bonding with the refractory. The sandwich test used by Lin et al. [12] supported their work about adherence properties of cement clinker on porous periclase-spinel refractory aggregates. It was observed that when the spinel content was $15-40 \mathrm{wt} . \%$, the refractory aggregate had not only a high clinker corrosion resistance but also a high coating adherence.

In practice, a coating will form if the conditions in the kiln are appropriate. However, the composition and the microstructure of the refractory used are also important to determine the quality of the coating. Thus, the objective of this investigation is to study different compositions of magnesia-spinel refractory bricks to improve coating adherence: additives (calcined alumina, limestone, hematite and zirconia) and firing temperature $\left(1500{ }^{\circ} \mathrm{C}\right.$ and $\left.1700{ }^{\circ} \mathrm{C}\right)$. It is expected that the addition of calcined alumina will influence the coating adherence due to the formation of fine spinel which easily reacts with clinker. Limestone and hematite were selected to ease the formation of liquid phase in the brick. The role of $\mathrm{ZrO}_{2}$ is to react with $\mathrm{CaO}$ from the clinker, generating calcium zirconate $\left(\mathrm{CaZrO}_{3}\right)$, which is reported to promote the formation of a protective coating.

\section{Materials and Methods}

Five different magnesia-spinel brick compositions fired at two temperatures, as shown in Table 1, were prepared in the laboratory. The main raw materials used were high purity dead burned magnesia (DBM), with bulk density of $3.3 \mathrm{~g} / \mathrm{cm}^{3}$ and $\mathrm{MgO}$ content of $98 \mathrm{wt} . \%$, and fused spinel (MA), with bulk density of $3.4 \mathrm{~g} / \mathrm{cm}^{3}$ and $\mathrm{Al}_{2} \mathrm{O}_{3}$ and $\mathrm{MgO}$ contents of $67 \mathrm{wt} . \%$ and $32 \mathrm{wt} . \%$, respectively. Two percent of the four selected additives were added: calcined alumina (average particle size of $5 \mu \mathrm{m}$ and purity of $99.6 \mathrm{wt} . \%$ ), limestone $<75 \mu \mathrm{m}$ (average particle size of $23 \mu \mathrm{m}$ and purity of $98.7 \mathrm{wt} . \%$ ), CaO-partially stabilized zirconia $<75 \mu \mathrm{m}$ (average particle size of $12 \mu \mathrm{m}$ and purity of $95.5 \mathrm{wt} . \%$ ), and hematite $<75 \mu \mathrm{m}$ (average particle of size $41 \mu \mathrm{m}$ and purity of $99.3 \mathrm{wt} . \%$ ).

Table 1. Compositions of magnesia-spinel bricks produced at the laboratory.

\begin{tabular}{ccccc}
\hline Composition & DBM (wt. $\%)$ & MA (wt. $\%)$ & Additive & Firing Temperature $\left({ }^{\circ} \mathbf{C}\right)$ \\
\hline A-1 & 80 & 20 & no & 1500 \\
A-2 & 78 & 20 & calc. alumina & 1500 \\
A-3 & 78 & 20 & limestone & 1500 \\
A-4 & 78 & 20 & hematite & 1500 \\
A-5 & 78 & 20 & zirconia & 1500 \\
A-6 & 80 & 20 & no & 1700 \\
A-7 & 78 & 20 & calc. alumina & 1700 \\
A-8 & 78 & 20 & limestone & 1700 \\
A-8 & 78 & 20 & hematite & 1700 \\
A-10 & 78 & 20 & zirconia & 1700 \\
\hline
\end{tabular}

The compositions were prepared by mixing the raw materials with $3 \mathrm{wt} . \%$ of an organic binder solution for $15 \mathrm{~min}$, in a roller mixer. Subsequently, $160 \times 85 \times 64 \mathrm{~mm}^{3}$ bricks were pressed using a laboratory hydraulic press at pressure of $210 \mathrm{MPa}$, and then dried at $120^{\circ} \mathrm{C}$ for $12 \mathrm{~h}$. The bricks were heat-treated under oxidizing conditions at $1500{ }^{\circ} \mathrm{C}$ for $5 \mathrm{~h}$ or $1700^{\circ} \mathrm{C}$ for $5 \mathrm{~h}$, in an electric muffle furnace.

After the heat treatment, the compositions were characterized in terms of bulk density (BD) and apparent porosity (AP) according to ISO 5017: 2015 standard; modulus of elasticity at room temperature (ME) according to ASTM C885 standard; cold crushing strength (CCS) 
according to ISO 10059-Part 2: 2014 standard; hot modulus of rupture (HMOR) at $120{ }^{\circ} \mathrm{C}$ and at $1485^{\circ} \mathrm{C}$ for $3 \mathrm{~h}$ according to ISO 5013: 2012 standard; gas permeability according to ASTM C577 standard; chemical composition by X-ray fluorescence using the PW2540 Philips spectrometer; study of mineralogical composition by X-ray diffraction (XRD) using PANalytical equipment, $X^{\prime}$ Pert PRO model where the analysis was performed in the $X^{\prime}$ Pert HighSore Plus program using the JCPDS-International Centre for Diffraction Data as database; and microstructural observations by means of reflected light optical microscope of Zeiss, AXIO Imager.A1m model.

The evaluation of the coating adherence on the refractory bricks was based on the sandwich method described in the previous work [13]. For the coating agent, a cement raw meal was collected from a Brazilian cement producer and ground to achieve $<75 \mu \mathrm{m}$. The typical properties of this meal are presented in Table 2. To prevent the transformation of $\beta C_{2} S$ into $\gamma C_{2} S$, which is accompanied by 10 to $12 \%$ volume expansion [14], thus prejudicial to the coating adherence upon cooling down the samples, $1 \mathrm{wt} . \%$ of boric acid was added to the cement meal. According to Zhao [14], chemical impurities, such as $\mathrm{Na}_{2} \mathrm{O}, \mathrm{P}_{2} \mathrm{O}_{5}$, $\mathrm{B}_{2} \mathrm{O}_{3}, \mathrm{Cr}_{2} \mathrm{O}_{3}$ and $\mathrm{K}_{2} \mathrm{O}$, are stabilizers of $\beta \mathrm{C}_{2} \mathrm{~S}$, which justifies the use of boric acid.

Table 2. Properties of the cement raw meal used in the sandwich coating test.

\begin{tabular}{|c|c|}
\hline \multicolumn{2}{|c|}{ Cement Raw Meal after Grinding } \\
\hline \multicolumn{2}{|c|}{ Particle Size Distribution $(\mu \mathrm{m})$} \\
\hline $\mathrm{d}_{98}$ & 124.0 \\
\hline $\mathrm{d}_{90}$ & 78.2 \\
\hline $\mathrm{d}_{75}$ & 44.7 \\
\hline $\mathrm{d}_{50}$ & 17.5 \\
\hline $\mathrm{d}_{25}$ & 5.6 \\
\hline $\mathrm{d}_{10}$ & 1.9 \\
\hline \multicolumn{2}{|c|}{ Chemical composition (wt.\%) } \\
\hline $\mathrm{CaO}$ & 66.7 \\
\hline $\mathrm{SiO}_{2}$ & 22.7 \\
\hline $\mathrm{Al}_{2} \mathrm{O}_{3}$ & 4.8 \\
\hline $\mathrm{Fe}_{2} \mathrm{O}_{3}$ & 2.4 \\
\hline $\mathrm{MgO}$ & 1.5 \\
\hline $\mathrm{Na}_{2} \mathrm{O}$ & 0.1 \\
\hline $\mathrm{K}_{2} \mathrm{O}$ & 0.8 \\
\hline $\mathrm{SO}_{3}$ & 0.5 \\
\hline \multirow{4}{*}{ XRD } & Calcite \\
\hline & Quartz \\
\hline & Muscovite \\
\hline & Chlorite \\
\hline
\end{tabular}

To perform the sandwich test, the coating agent was placed between the upper and bottom portion of brick sample with $55 \times 36 \times 36 \mathrm{~mm}^{3}$ dimensions each piece and wrapped with a tape. A dead weight of $690 \mathrm{~g}$ was applied on top of the sandwich, which is equivalent to a load of $5.3 \mathrm{kPa}$, and then the sandwiches were introduced in the electric furnace. The coating test was carried out at $1500{ }^{\circ} \mathrm{C}$ for $5 \mathrm{~h}$ and during the cooling down step, the rate of $50{ }^{\circ} \mathrm{C} / \mathrm{h}$ was applied below $1000^{\circ} \mathrm{C}$ to prevent $\gamma \mathrm{C}_{2} \mathrm{~S}$ formation.

The adherence strength of the clinker was considered as the average value of the cold modulus of rupture (CMOR) performed after the sandwich test, using ISO 13765-4: 2012 standard. After the CMOR test, some clinker-brick interfaces were analyzed by means of optical microscopy, scanning electron microscopy (Jeol, JSM-7100FLV model) coupled with energy dispersive X-ray spectrometer (Aztec Energy using X-Max 80 detector), and X-ray microtomography (micro-CT scanner of Bruker SkyScan 1174, with $50 \mathrm{kV}$ source voltage, $800 \mu \mathrm{A}$ source current and $10.03 \mu \mathrm{m}$ image pixel size) using a $1 \mathrm{~mm}$ aluminum filter. In the latter test, samples of $8.5 \times 8 \times 6 \mathrm{~mm}^{3}$ were attached to a stage that rotated $180^{\circ}$ with images acquired at every $0.7^{\circ}$. The acquired shadow projections (16-bit TIFF format) were further reconstructed into $2 \mathrm{D}$ slices using the NRecon software interface 
(v.1.7.4.6, Skyscan, Bruker micro-CT, Belgium). Quantitative analyses were made using CTAn software (v.1.18.8.0, Bruker micro-CT, Belgium) and CTVox software (v.3.3.0, Skyscan, Bruker micro-CT, Belgium) was used for 3D volumetric visualization.

\section{Results and Discussion}

\subsection{Characterization of Magnesia-Spinel Brick Compositions}

Tables 3 and 4 show the properties of A- 1 to A-10 compositions. Overall, the increase in the firing temperature affected all properties, contributing positively to an increase in bulk density, hot modulus of rupture at $1485{ }^{\circ} \mathrm{C}$ and permeability, and to a decrease in apparent porosity and modulus of elasticity.

Table 3. Properties of magnesia-spinel brick compositions fired at $1500{ }^{\circ} \mathrm{C}$.

\begin{tabular}{|c|c|c|c|c|c|}
\hline Brick & A-1 & A-2 & A-3 & A-4 & A-5 \\
\hline $\mathrm{BD}\left(\mathrm{g} / \mathrm{cm}^{3}\right)$ & 2.98 & 2.98 & 2.96 & 2.99 & 3.00 \\
\hline $\mathrm{AP}(\%)$ & 14.7 & 14.6 & 14.3 & 14.8 & 14.9 \\
\hline $\mathrm{ME}(\mathrm{GPa})$ & 34 & 30 & 31 & 30 & 31 \\
\hline CCS (MPa) & 86 & 83 & 70 & 84 & 90 \\
\hline HMOR at $1200^{\circ} \mathrm{C}-3 \mathrm{~h}(\mathrm{MPa})$ & 8.6 & 8.4 & 4.5 & 9.2 & 10.0 \\
\hline $\mathrm{HMOR}$ at $1485^{\circ} \mathrm{C}-3 \mathrm{~h}(\mathrm{MPa})$ & 1.8 & 1.5 & 0.5 & 1.0 & 2.0 \\
\hline Permeability $(\mathrm{cD})$ & 18 & 18 & 32 & 29 & 21 \\
\hline \multicolumn{6}{|c|}{ Chemical Composition (wt.\%) } \\
\hline $\mathrm{MgO}$ & 87.6 & 84.8 & 85.0 & 83.5 & 86.1 \\
\hline $\mathrm{Al}_{2} \mathrm{O}_{3}$ & 11.0 & 13.8 & 12.4 & 12.8 & 10.0 \\
\hline $\mathrm{CaO}$ & 0.8 & 0.7 & 1.8 & 0.8 & 0.8 \\
\hline $\mathrm{SiO}_{2}$ & 0.2 & 0.2 & 0.2 & 0.2 & 0.3 \\
\hline $\mathrm{Fe}_{2} \mathrm{O}_{3}$ & 0.4 & 0.4 & 0.4 & 2.5 & 0.4 \\
\hline $\mathrm{ZrO}_{2}$ & 0.0 & 0.0 & 0.0 & 0.0 & 2.1 \\
\hline XRD & $\begin{array}{c}\mathrm{MgO} \\
\mathrm{MA} \\
\beta \mathrm{C}_{2} \mathrm{~S}\end{array}$ & $\begin{array}{c}\mathrm{MgO} \\
\mathrm{MA} \\
\beta \mathrm{C}_{2} \mathrm{~S}\end{array}$ & $\begin{array}{c}\mathrm{MgO} \\
\mathrm{MA} \\
\mathrm{Q} \text { phase } \\
\mathrm{C}_{12} \mathrm{~A}_{7}\end{array}$ & $\begin{array}{l}\mathrm{MgO} \\
\mathrm{MA} \\
\mathrm{MF}\end{array}$ & $\begin{array}{c}\mathrm{MgO} \\
\mathrm{MA} \\
\mathrm{Cub} . \mathrm{ZrO}_{2} \\
\mathrm{CaZrO}_{3}\end{array}$ \\
\hline
\end{tabular}

Table 4. Properties of magnesia-spinel brick compositions fired at $1700{ }^{\circ} \mathrm{C}$.

\begin{tabular}{|c|c|c|c|c|c|}
\hline Brick & A-6 & A-7 & A-8 & A-9 & A-10 \\
\hline $\mathrm{BD}\left(\mathrm{g} / \mathrm{cm}^{3}\right)$ & 2.98 & 2.99 & 2.98 & 2.99 & 3.03 \\
\hline $\mathrm{AP}(\%)$ & 14.5 & 14.4 & 13.5 & 14.3 & 14.0 \\
\hline $\mathrm{ME}(\mathrm{GPa})$ & 28 & 22 & 31 & 25 & 27 \\
\hline CCS (MPa) & 88 & 74 & 54 & 83 & 86 \\
\hline $\mathrm{HMOR}$ at $1200^{\circ} \mathrm{C}-3 \mathrm{~h}(\mathrm{MPa})$ & 7.0 & 6.4 & 6.1 & 7.8 & 7.6 \\
\hline $\mathrm{HMOR}$ at $1485^{\circ} \mathrm{C}-3 \mathrm{~h}(\mathrm{MPa})$ & 1.4 & 1.7 & 0.7 & 1.3 & 2.4 \\
\hline Permeability (cD) & 35 & 35 & 48 & 46 & 59 \\
\hline \multicolumn{6}{|c|}{ Chemical Composition (wt.\%) } \\
\hline $\mathrm{MgO}$ & 87.2 & 86.4 & 87.1 & 83.9 & 84.0 \\
\hline $\mathrm{Al}_{2} \mathrm{O}_{3}$ & 11.1 & 12.1 & 10.4 & 12.4 & 12.3 \\
\hline $\mathrm{CaO}$ & 0.8 & 0.7 & 1.7 & 0.8 & 0.8 \\
\hline $\mathrm{SiO}_{2}$ & 0.2 & 0.2 & 0.2 & 0.2 & 0.2 \\
\hline $\mathrm{Fe}_{2} \mathrm{O}_{3}$ & 0.4 & 0.4 & 0.4 & 2.6 & 0.5 \\
\hline $\mathrm{ZrO}_{2}$ & 0.0 & 0.0 & 0.0 & 0.0 & 2.0 \\
\hline \multirow{3}{*}{ XRD } & $\mathrm{MgO}$ & $\mathrm{MgO}$ & $\mathrm{MgO}$ & $\mathrm{MgO}$ & $\mathrm{MgO}$ \\
\hline & MA & MA & MA & MA & MA \\
\hline & $\beta C_{2} S$ & $\beta C_{2} S$ & Q phase & $\mathrm{MF}$ & $\begin{array}{c}\text { Cub. } \mathrm{ZrO}_{2} \\
\mathrm{CaZrO}_{3}\end{array}$ \\
\hline
\end{tabular}

It is obvious that the higher the firing temperature, the more liquid forms, enhancing properties such as density and porosity. However, the permeability also increased which may be related to the pore size growth that results from pore coalescence with sintering 
process. Permeability is considered the most important physical property of magnesiaspinel refractory bricks which affects coatability, since it can promote clinker infiltration and contribute to a physical coating adherence. At the same time, it is observed that the use of high firing temperature decreased the cold crushing strength for calcined alumina and limestone additions, and hot modulus of rupture at $1200{ }^{\circ} \mathrm{C}$ for all additions.

Similarly to increasing firing temperature, the use of additives also influenced all properties. Zirconia contributed positively to increase in bulk density, hot modulus of rupture at $1200{ }^{\circ} \mathrm{C}$ and $1485^{\circ} \mathrm{C}$, and permeability, which suggests that this addition is beneficial to the sintering and densification, as also observed by Meng et al. [11]. On the contrary, limestone has a negative effect on these properties, except in increasing permeability. Due to the formation of in situ spinel, the addition of calcined alumina strongly reduces the modulus of elasticity of the refractory. The greatest effect of the hematite addition was the increase in permeability.

As expected, there was an increase in the corresponding oxide in the chemical composition when the additives were used. In general, when $2 \mathrm{wt} . \%$ of calcined alumina was added to the composition, the $\mathrm{Al}_{2} \mathrm{O}_{3}$ content increased from 11.0 to $13.0 \mathrm{wt} . \%$. For the addition of $2 \mathrm{wt} . \%$ of limestone, the $\mathrm{CaO}$ content increased from 0.8 to $1.8 \mathrm{wt} . \%$, and for the addition of $2 \mathrm{wt} . \%$ of hematite, the $\mathrm{Fe}_{2} \mathrm{O}_{3}$ content increased from 0.4 to $2.6 \mathrm{wt} . \%$. When $2 \mathrm{wt} . \%$ of zirconia was added, the $\mathrm{ZrO}_{2}$ content increased from 0 to $2.0 \mathrm{wt} . \%$ since this oxide was not originally present in the raw materials.

The XRD patterns are illustrated in Figures 1 and 2. The additives were recognized through the presence of mayenite and $Q$ phase (for limestone), magnesium ferrite (for hematite), cubic zirconia and calcium zirconate (for $\mathrm{CaO}$-partially stabilized zirconia). The presence of mayenite $\left(\mathrm{C}_{12} \mathrm{~A}_{7}\right)$ and $Q$ phase $\left(\mathrm{Ca}_{20} \mathrm{Al}_{26} \mathrm{Mg}_{3} \mathrm{Si}_{3} \mathrm{O}_{68}\right)$ means that the spinel from the brick reacted with calcium oxide from limestone, forming these low refractoriness phases $\left(\mathrm{T}_{\mathrm{mp}}=1390^{\circ} \mathrm{C}\right.$ for $\mathrm{C}_{12} \mathrm{~A}_{7}, \mathrm{~T}_{\mathrm{mp}}=1300$ to $1400^{\circ} \mathrm{C}$ for $\mathrm{Q}$ phase [15]). Therefore, the addition of limestone contributes to the formation of more liquid phases, resulting in the drop of hot properties obtained by A-3 and A- 8 compositions. Part of the added zirconia reacted with the calcium oxide from the raw materials to form calcium zirconate $\left(\mathrm{CaZrO}_{3}\right)$, a very refractory material $\left(\mathrm{T}_{\mathrm{mp}}=2340^{\circ} \mathrm{C}\right)$ what justifies the enhance in hot properties. For calcined alumina addition, no new phases were detected, which means that all alumina reacted with magnesia in the matrix, forming in situ spinel.

Figures 3 and 4 illustrate the microstructure of A-1 to A-10. All compositions presented homogeneous distribution of magnesia and fused spinel raw materials. Good sintering degree was obtained by A-4, A-6, A-7, A-9 and A-10 compositions. A refractory structure with a suitable sintering degree presents larger bonds among the particles, which may easily promote the reaction with clinker phases to form the coating. The addition of limestone to A-3 and A-8 resulted in partial corrosion of fused spinel and excessive sintering degree, which is related to the formation of $C_{12} A_{7}$ and $Q$ phase. The other compositions (A-1, A-2 and A-5), fired at $1500{ }^{\circ} \mathrm{C}$, presented reasonable sintering degree. 


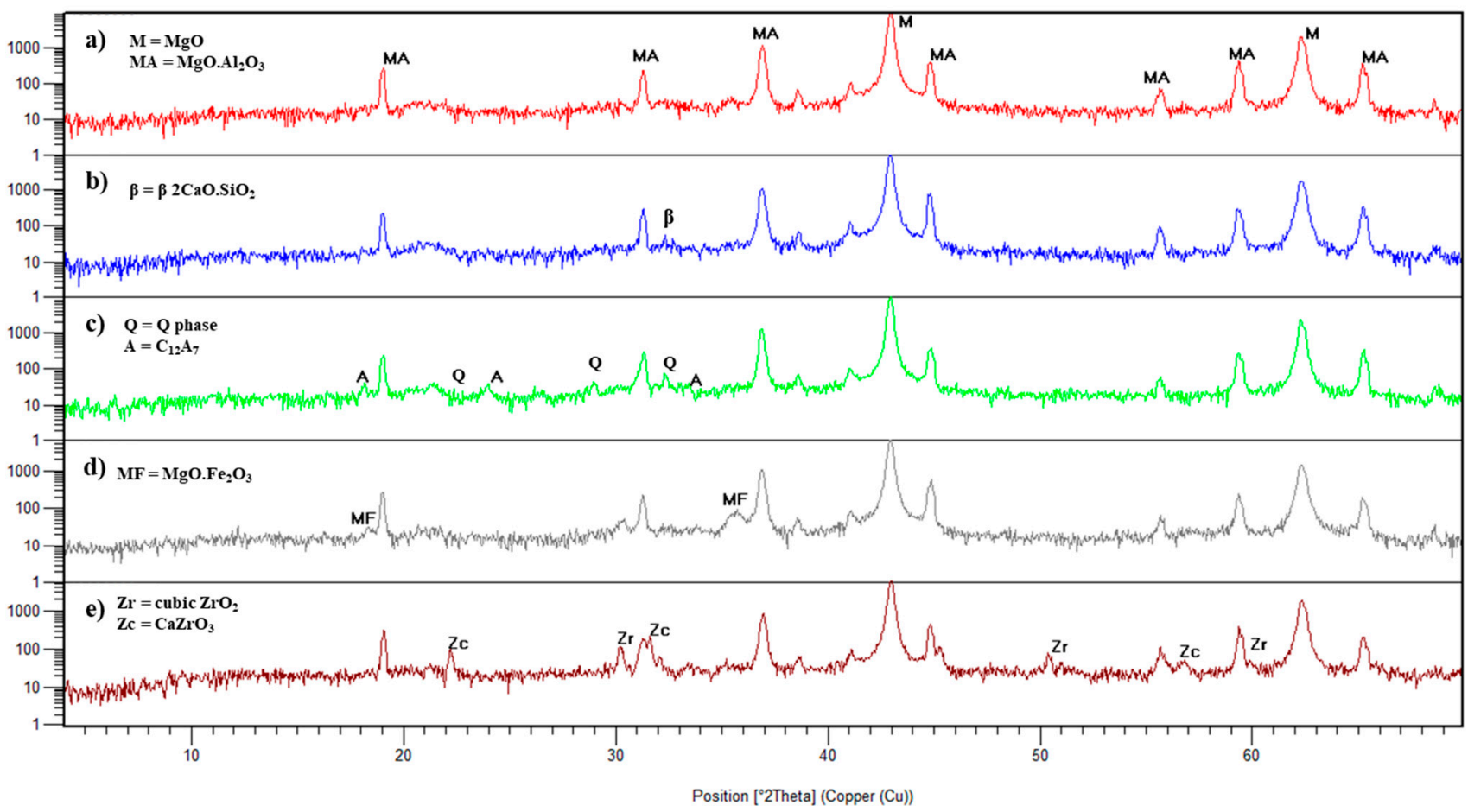

Figure 1. X-ray diffraction patterns of compositions (a) A-1, (b) A-2, (c) A-3, (d) A-4 and (e) A-5.

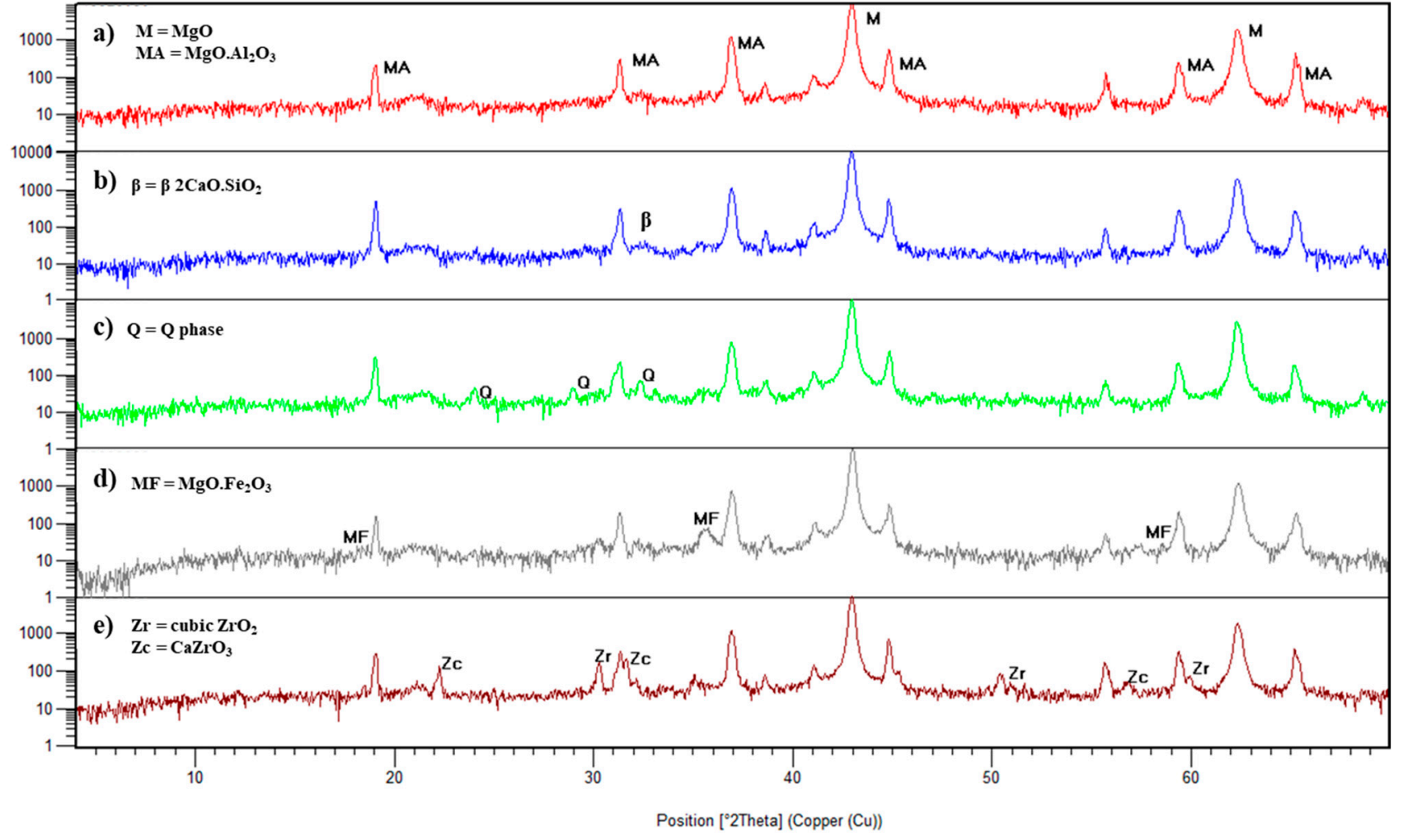

Figure 2. X-ray diffraction patterns of compositions (a) A-6, (b) A-7, (c) A-8, (d) A-9 and (e) A-10. 


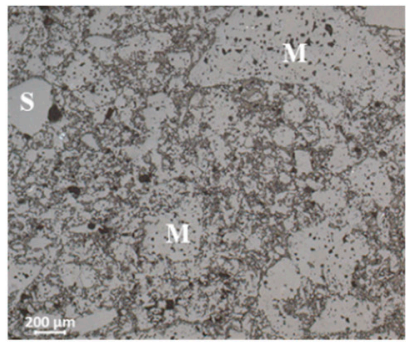

a)

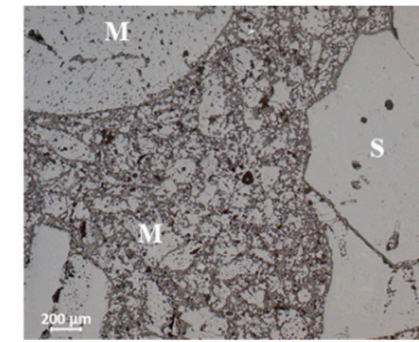

b)

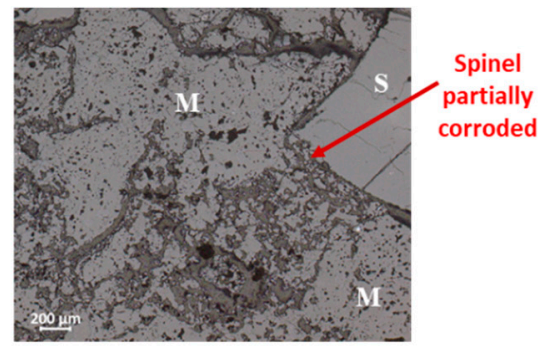

c)

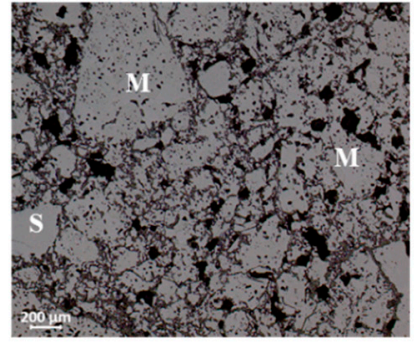

d)

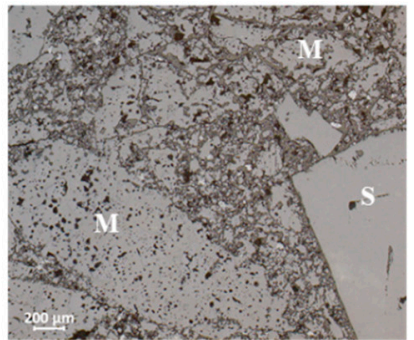

e)

Figure 3. Microstructure of compositions (a) A-1, (b) A-2, (c) A-3, (d) A-4 and (e) A-5 (M = magnesia, S = fused spinel) - 50× magnification.

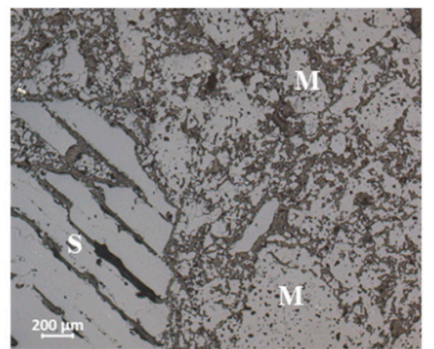

a)

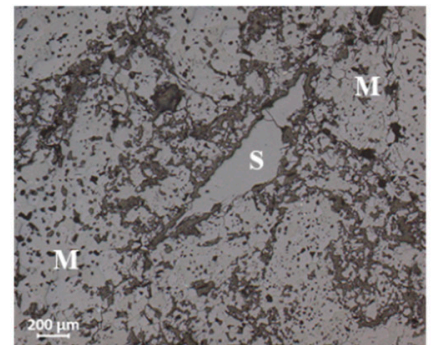

b)

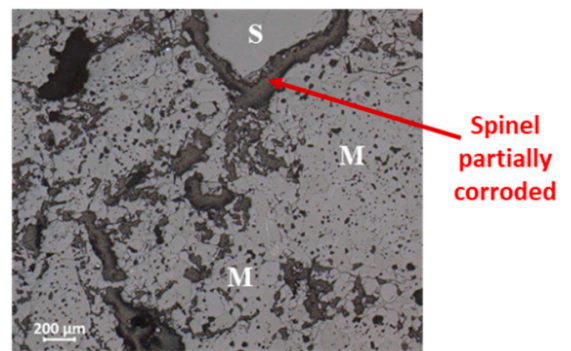

c)

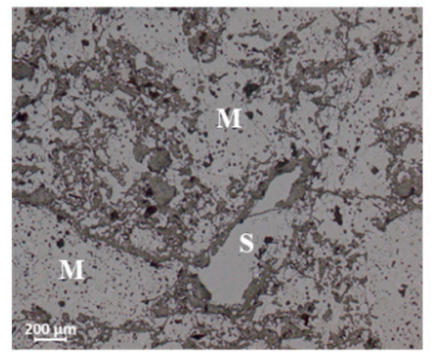

d)

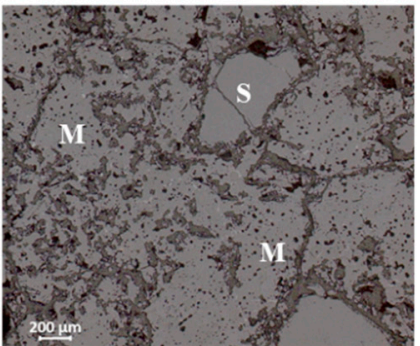

e)

Figure 4. Microstructure of compositions (a) A-6, (b) A-7, (c) A-8, (d) A-9 and (e) A-10 (M = magnesia, S = fused spinel) - 50× magnification.

\subsection{Coating Test}

The evaluation of the coating adherence ability by the sandwich coating test for A-1 to A-10 compositions is described in Figure 5. The highest coating strength was obtained by A-3 (limestone and $1500{ }^{\circ} \mathrm{C}$ ), which presented $3.3 \mathrm{MPa}$ in cold modulus of rupture test. This composition was followed by A-8 (limestone and $1700{ }^{\circ} \mathrm{C}$ ), with $2.9 \mathrm{MPa}$, and A-6 (no additions and $1700{ }^{\circ} \mathrm{C}$ ), with $2.7 \mathrm{MPa}$. These values match the results between 0 and $4 \mathrm{MPa}$ obtained by Guo et al. [3], and the results between 0 to 1.4 MPa obtained by Lin et al. [12], using the sandwich coating test. 


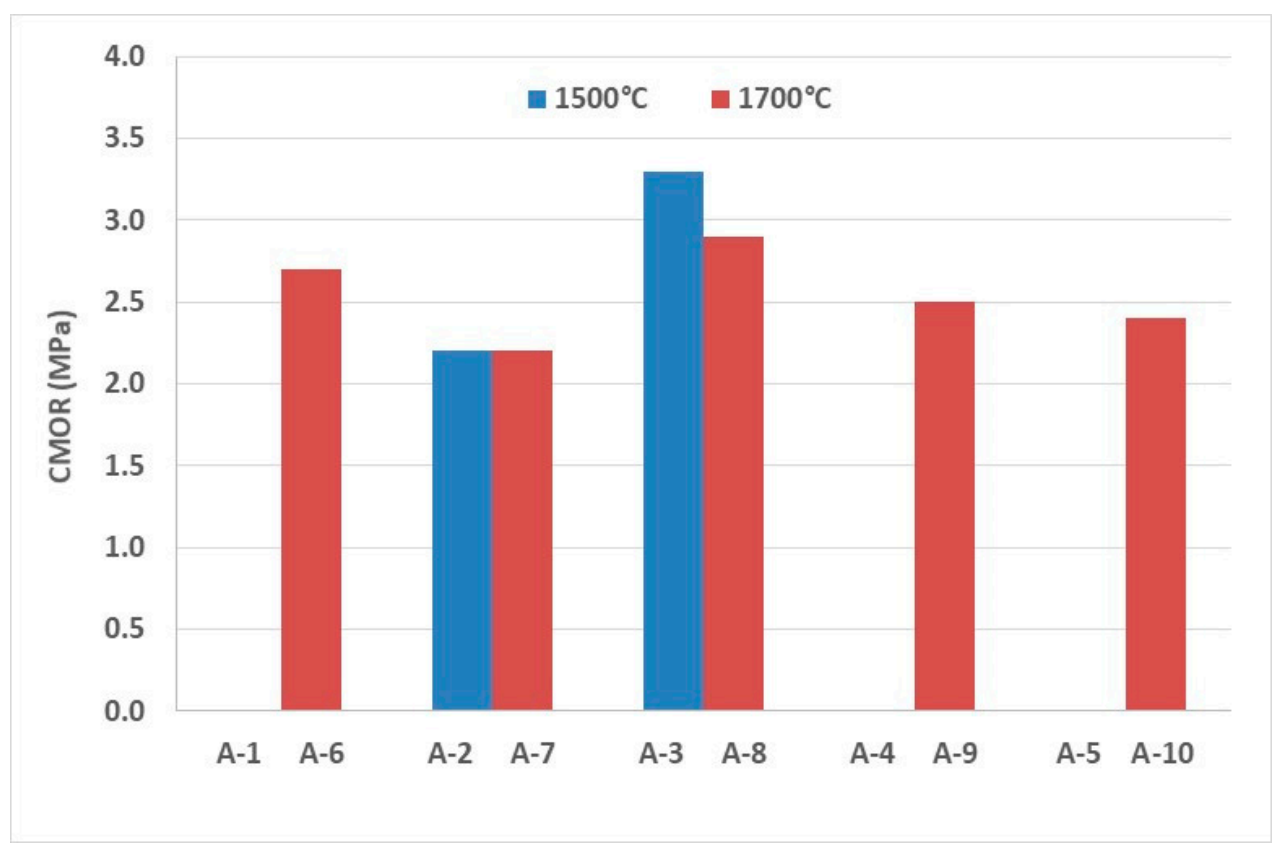

Figure 5. Cold modulus of rupture of magnesia-spinel brick compositions after the sandwich coating test.

There are two common features when comparing the three best compositions in terms of coating: addition of limestone and high firing temperature. The calcium from limestone addition reacts with spinel from the brick, forming low refractoriness phases and contributing to liquid phase formation which is essential to the coating adherence on magnesia-spinel bricks. Mayenite $\left(\mathrm{C}_{12} \mathrm{~A}_{7}\right)$ and $\mathrm{Q}$ phase $\left(\mathrm{Ca}_{20} \mathrm{Al}_{26} \mathrm{Mg}_{3} \mathrm{Si}_{3} \mathrm{O}_{68}\right)$ were identified in $\mathrm{XRD}$ of the compositions with limestone, in addition to partial corrosion of fused spinel grains observed in the microstructure. The use of high firing supports the migration of impurities in the raw materials to the liquid phase of the refractory, as well as guaranteeing a well-sintered refractory structure and increased permeability, all contributing positively to the coating adherence. It must be pointed out that A-3, A-6 and A-8 compositions showed permeability higher than $30 \mathrm{cD}$ and good to excessive sintering degree.

It is observed that the addition of hematite and zirconia to magnesia-spinel bricks in order to improve coating adherence is only effective if combined with high firing temperature. High firing temperature is important to elevate permeability and to improve sintering degree, leading to optimal coating adherence, as previously discussed. Moreover, when adding zirconia, part of it reacts with calcium oxide from the brick and another part reacts with lime phases from the clinker, forming calcium zirconate $\left(\mathrm{CaZrO}_{3}\right)$ and helping the formation of a protective coating $[8,9,16]$. In the case of hematite addition, the formation of magnesium ferrite contributes to the liquid phase formation, which is essential for adhering coating on magnesia-spinel bricks [3]. Tokunaga et al. [7] had also observed coating stability by the addition of pure iron oxides.

However, for calcined alumina and limestone additions, the increase in the firing temperature did not significantly change the coating strength. It is easily understood that the addition of calcined alumina increases the spinel content and promotes the formation of more liquid phase. This is in line with the results obtained by Lin et al. [12], where the greater the spinel content, the higher the content and the viscosity of the liquid phase, affecting the adherence property for compositions with spinel content lower than $50 \mathrm{wt} . \%$. As in situ spinel is totally formed after firing at $1500{ }^{\circ} \mathrm{C}$, there was no improvement with the increase in firing temperature. For limestone, the same conclusions are made, but the increase in the liquid phase is due to the presence of $Q$ phase. 


\subsection{Microstructure Observations}

The clinker-brick interface of A-1 and A-3 compositions were selected to be observed under optical microscope after the sandwich coating test, as they represent extreme cases of coating strength. Figure 6 shows that there are two different zones for A-1 (changed area and unaltered area) and three zones for A-3 (coating, changed area and unaltered area). Both microstructures were infiltrated by clinker liquid phase but to a lesser extent for A-1. Stable coating adherence on the brick surface, with $1500 \mu \mathrm{m}$ thickness, is noticed only for A-3. After the altered area, the microstructure is typical for A-1 and A-3 compositions. Pictures with higher magnification were taken at the clinker-brick interface, as highlighted in Figure 7.

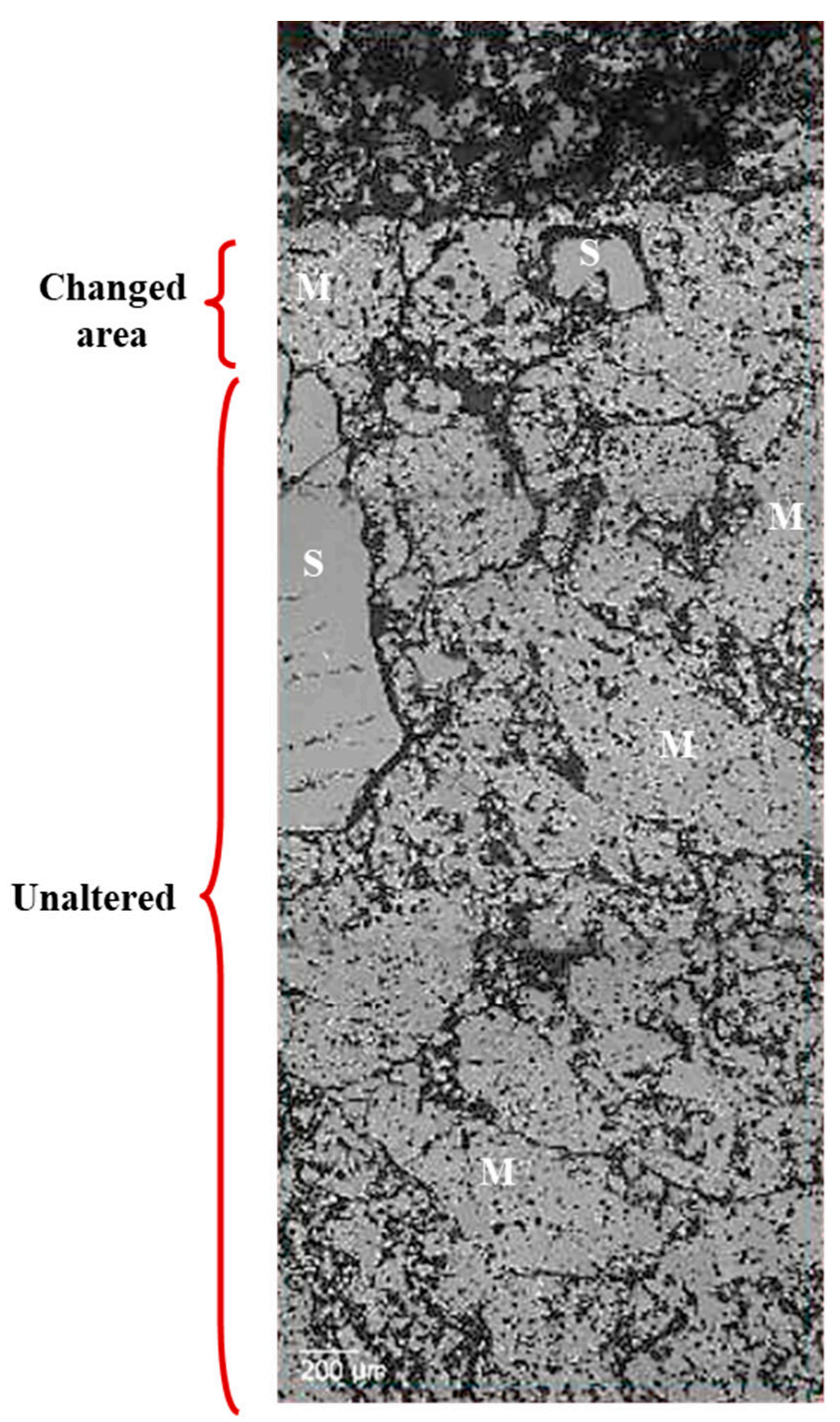

a)

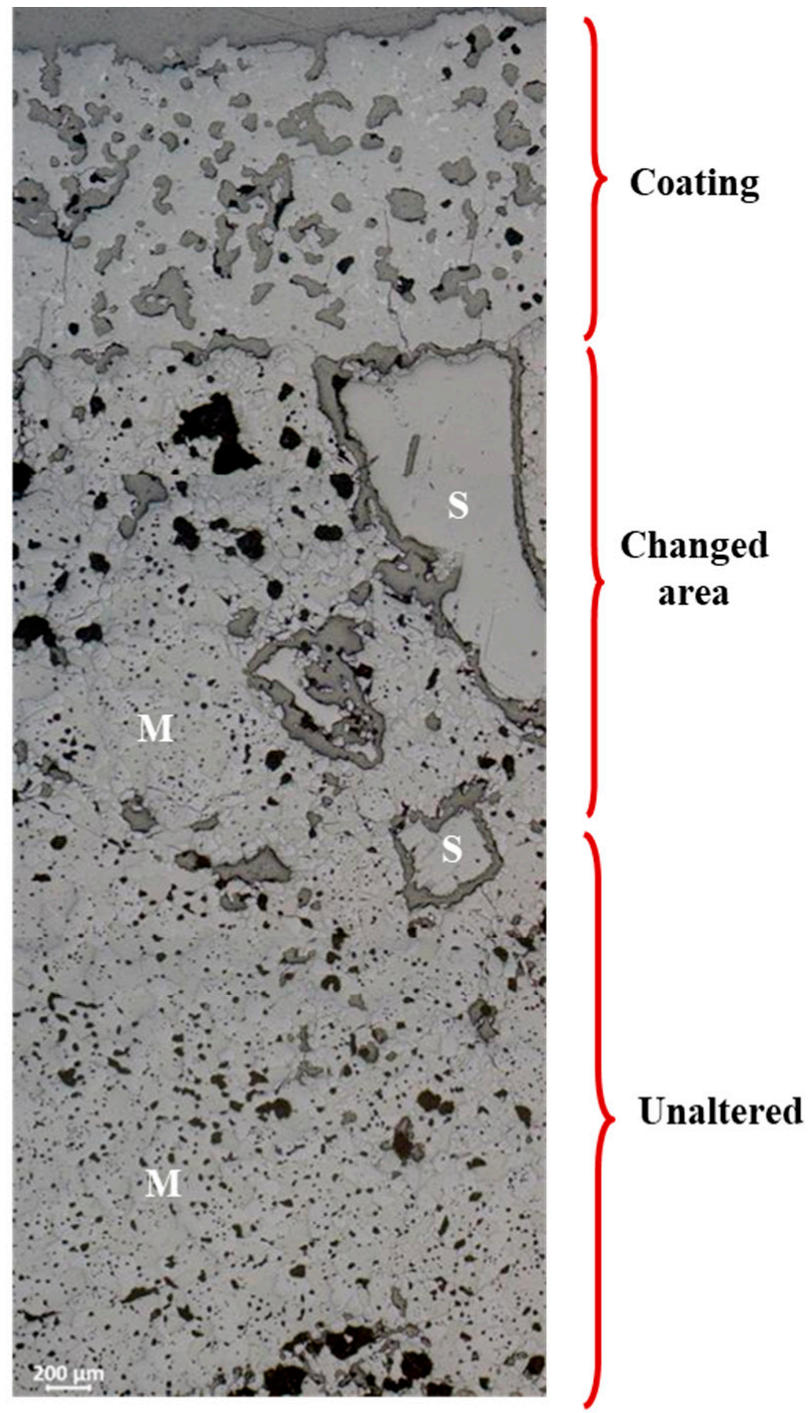

b)

Figure 6. Microstructure of the clinker-brick interface of composition (a) A-1 (b) A-3 after the sandwich coating test ( $\mathrm{M}=$ magnesia, $\mathrm{S}=$ fused spinel $)-50 \times$ magnification. 


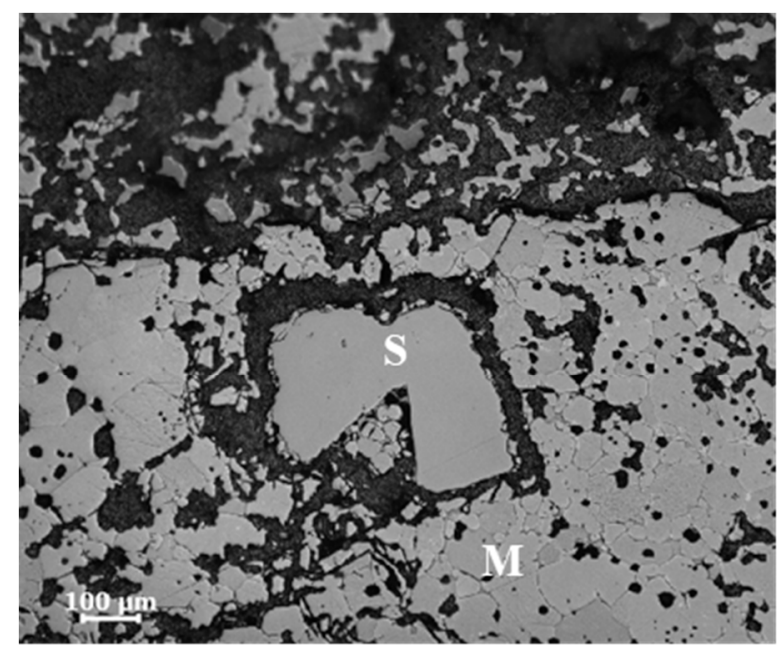

a)

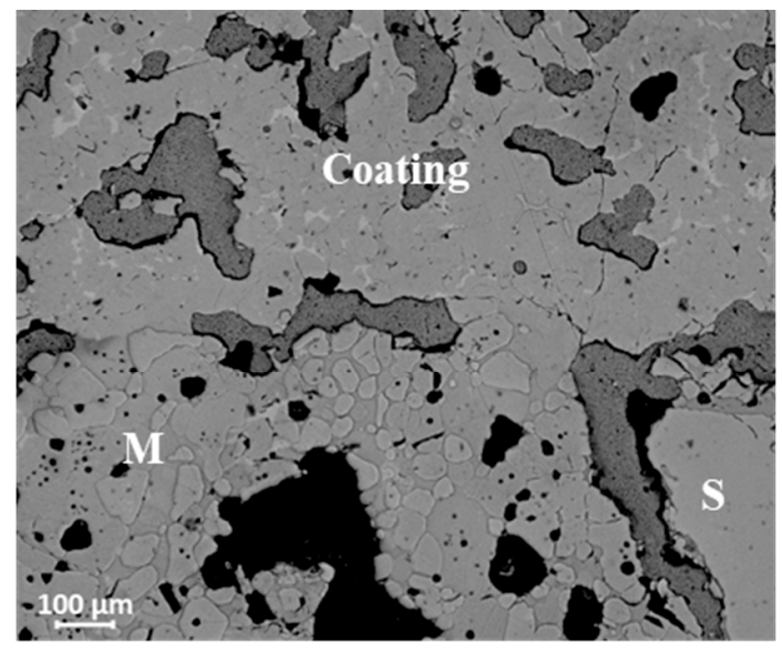

b)

Figure 7. Microstructure of the clinker-brick interface of composition (a) A-1 (b) A-3 after the sandwich coating test $(\mathrm{M}=$ magnesia, $\mathrm{S}=$ fused spinel $)-100 \times$ magnification.

A partial corrosion of the fused spinel by clinker phases can be observed in the area just below the interface for both compositions, but the disintegration of magnesia grains is more evident for A-3. Although magnesia did not react with clinker phases, it is dissolved by the liquid composed of the main oxides present in the clinker, namely, $\mathrm{CaO}, \mathrm{SiO}_{2}, \mathrm{Al}_{2} \mathrm{O}_{3}$ and $\mathrm{Fe}_{2} \mathrm{O}_{3}$, which is analogous to a sintering process in the presence of liquid phase $[3,6]$. Bonding is also noticed between magnesia grains and coating in the microstructure corresponding to the A-3 composition.

The SEM-EDS analysis of the selected interfaces after the sandwich test is illustrated in Figure 8. The mapping of the region shows the distribution of chemical elements that constitute the coating and brick areas in different colors. It is observed, for A-1 composition, that elements $\mathrm{Ca}, \mathrm{Si}$ and $\mathrm{O}$ are predominant at the top part corresponding to the coating area, and elements $\mathrm{Mg}$ and $\mathrm{O}$ are predominant at the bottom part corresponding to the brick area. For A-3, element $\mathrm{Al}$ is also present in the coating area, in addition to $\mathrm{Ca}$, $\mathrm{Si}$, and $\mathrm{O}$. In the brick area, elements $\mathrm{Mg}$ and $\mathrm{O}$ are predominant in the grains, and $\mathrm{Ca}, \mathrm{Si}, \mathrm{Al}$ and $\mathrm{O}$ are predominant in the liquid phase permeating through the grains.

Because no expressive amount of $\mathrm{Al}$ and, therefore, liquid phase, was detected in the clinker and brick areas for A-1, higher magnification in the interface with chemical composition by EDS for phase identification was carried out. Figure 9 shows that in the clinker area of $A-1$, only phases $C_{2} S$ and $C_{3} A$ were identified. No elements and phases were detected in the grain boundaries. In the brick, $\mathrm{MgO}$ grains are predominant, but a small area with $\mathrm{C}_{2} \mathrm{~S}$ and spinel was also observed. Thus, the absence of liquid phase in both areas explains the low coating adherence observed for A-1 composition. On the contrary, there are at least two different types of liquid phase in the clinker area of A-3: one more predominant and richer in $\mathrm{C}_{3} \mathrm{~A}$ (point 1 ), and another one located in the dark grey pockets and richer in $Q$ phase (points 3 and 5), as illustrated in Figure 9. In the brick area, two different liquid phase compositions were also identified, richer in $\mathrm{C}_{2} \mathrm{~S}$ (point 6) and richer in $Q$ phase (point 7). 

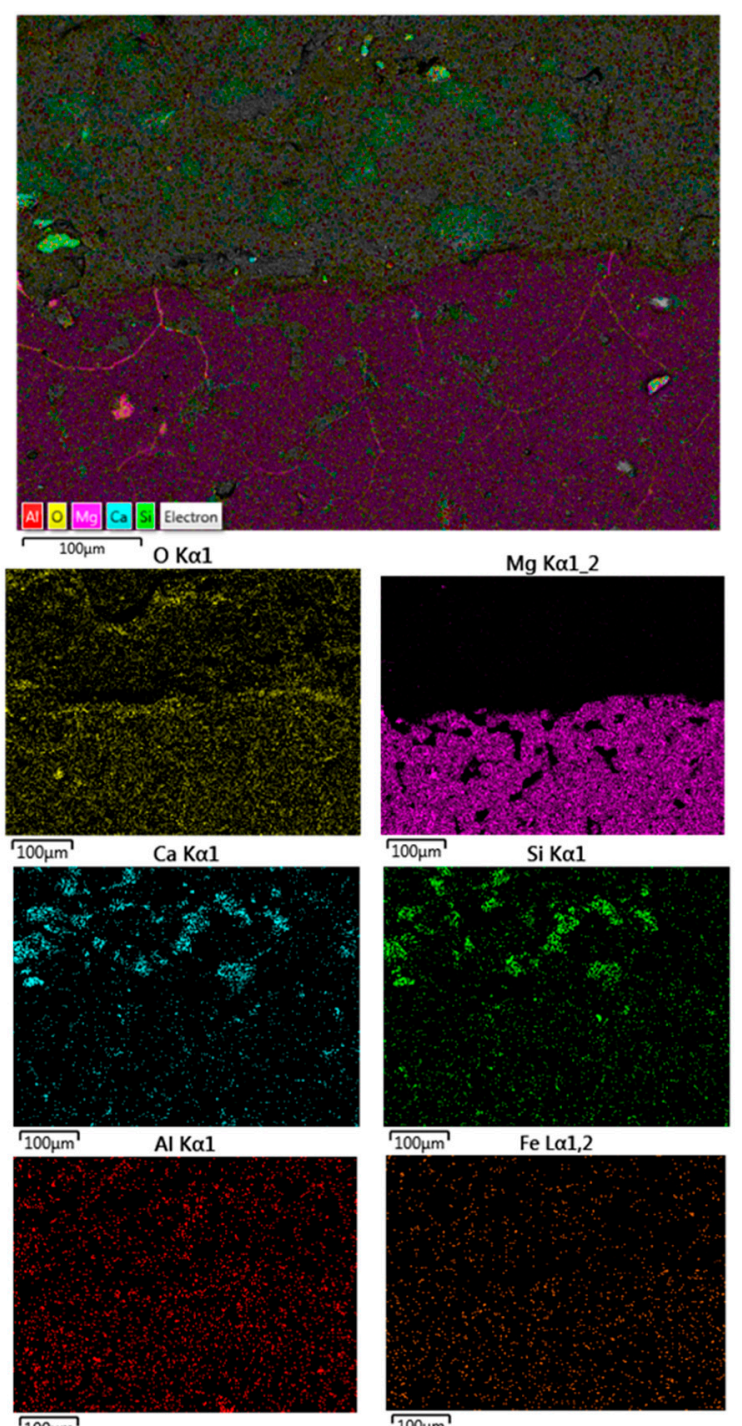

$\overline{100 \mu \mathrm{m}}$
Mg Ka1_2

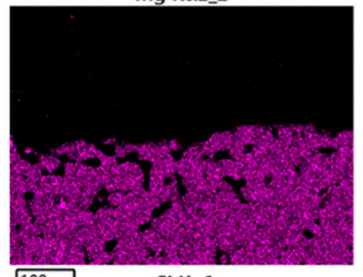

$\widehat{100 \mu \mathrm{m}}$

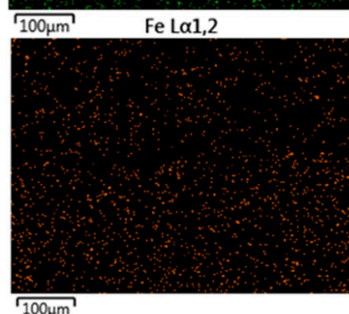

a)

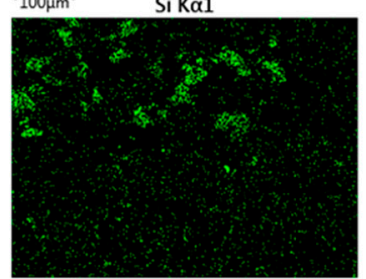

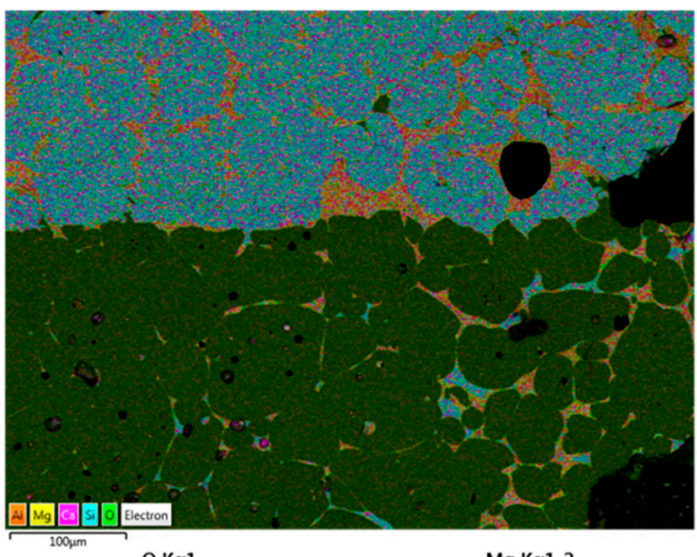

$\mathrm{OK \alpha} 1$
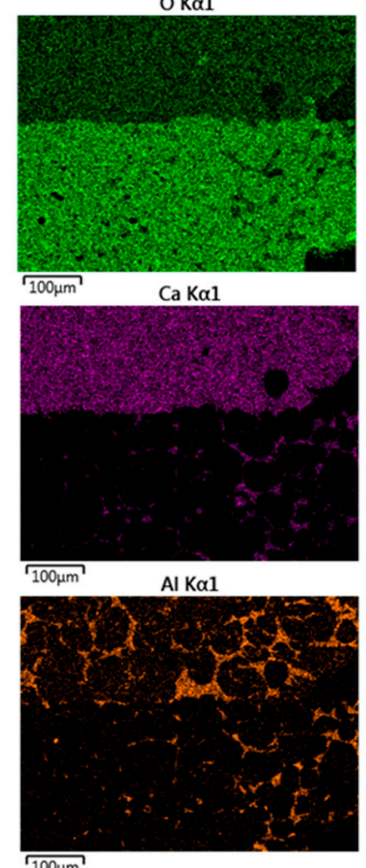

$\sqrt{100 \mu \mathrm{m}}$

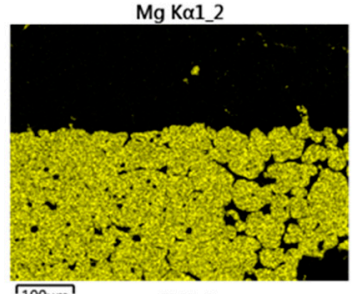

Si K $\alpha 1$

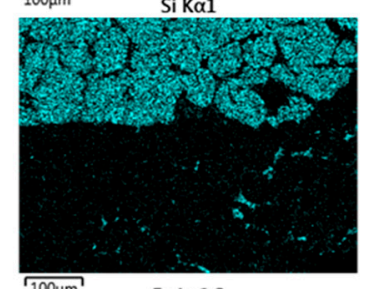

$100 \mu \mathrm{m} \quad \mathrm{Fe} \mathrm{L} \alpha 1,2$

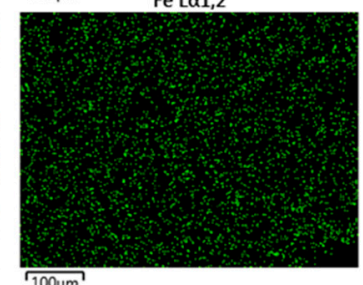

b)

Figure 8. SEM micrograph of the clinker-brick interface of composition (a) A-1 (b) A-3 after the sandwich coating test$200 \times$ magnification.

These analyses demonstrate that the liquid phase at the clinker-brick interface of A-3 composition is composed of brick and clinker components as a result of the reaction between them. Therefore, the resulting liquid phase is the link between the clinker and the brick, and it is essential to form coating in magnesia-spinel bricks. For A-1, SEM analysis did not show an abundant liquid phase, and consequently, no coating was adhered to the brick surface. 


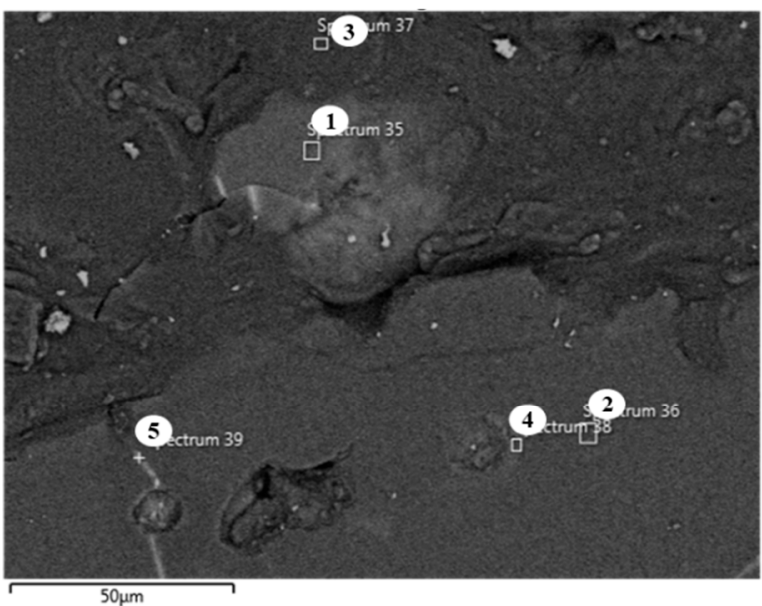

1: $\mathrm{C}_{2} \mathrm{~S}+\mathrm{C}_{3} \mathrm{~A} ; 2: \mathrm{MgO} ; 3$ : no phase detected; $4: \mathrm{C}_{2} \mathrm{~S}$ + MA, 5: MgO

a)

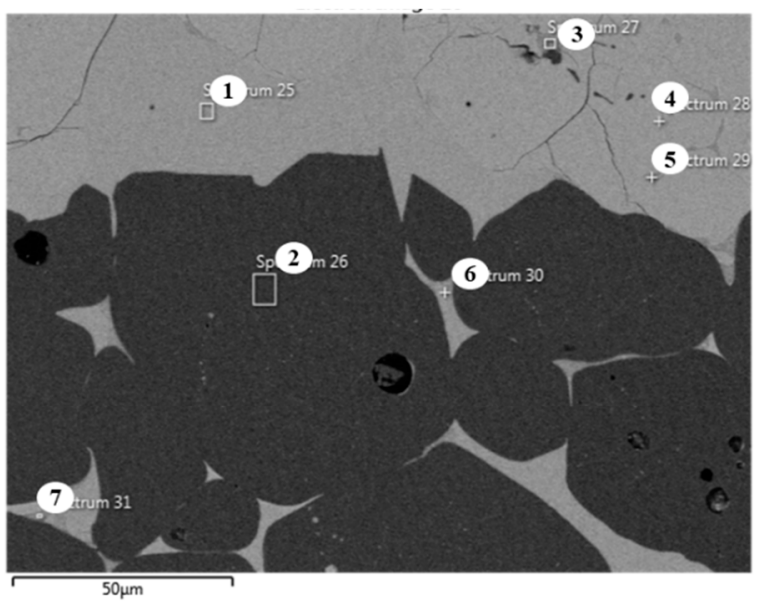

1: $\mathrm{C}_{3} \mathrm{~A}+\mathrm{C}_{2} \mathrm{~S}+\mathrm{Q}$ phase; $2: \mathrm{MgO} ; \mathbf{3}: \mathrm{Q}$ phase $+\mathrm{C}_{3} \mathrm{~A} ; \mathbf{4}$ : $\mathrm{C}_{2} \mathrm{~S}+\mathrm{C}_{3} \mathrm{~A}, 5$ : Q phase $+\mathrm{C}_{3} \mathrm{~A} ; 6$ : $\mathrm{C}_{2} \mathrm{~S}+\mathrm{MgO}+\mathrm{MA} ; \mathbf{7}$ : $Q$ phase $+\mathrm{C}_{3} \mathrm{~A}$.

b)

Figure 9. SEM micrograph of the clinker-brick interface of composition: (a) A-1, (b) A-3 after the sandwich coating test-700 $\times$ magnification.

\subsection{Micro-CT Analysis}

For visual observation of the effect of coating formation on magnesia-spinel bricks, A-1 and A-3 compositions were again selected to be examined by means of X-ray microtomography (micro-CT) after the sandwich coating test. Micro-CT is a non-destructive method that provides 3D images of the internal structure of a material at a spatial resolution better than 1 micrometer [17]. During the exposition, X-rays interact with the sample and are attenuated depending on the density of the material, the sample size, the atomic number of the elements as well as the wavelength of the X-rays [18]. In general, for a fixed $X$-ray photon energy, elements with lower atomic number absorb less than elements with higher atomic number [17].

Figure 10 presents the 3D model reconstruction of the coating and the brick areas, and the pore size distribution histogram of the brick area for both samples. The structural differences in the image for A-3, which presented the coating adhered to the surface, can be observed. It is possible to identify the interconnectivity between clinker and brick due to the difference in brightness, which is a function of the atomic number $(Z)$ of the absorbing element in each area. As coating is mainly rich in $\mathrm{Ca}(Z=20)$ and $\mathrm{Si}(Z=14)$, whose atomic numbers are higher compared to $\mathrm{Mg}(Z=12)$ and $\mathrm{Al}(Z=13)$ in the brick area, it presents greater $X$-ray attenuation resulting in the formation of contrast in the micro-CT images represented by the lighter region. On the other hand, A-1 did not present adhered coating, so no lighter region is observed. 

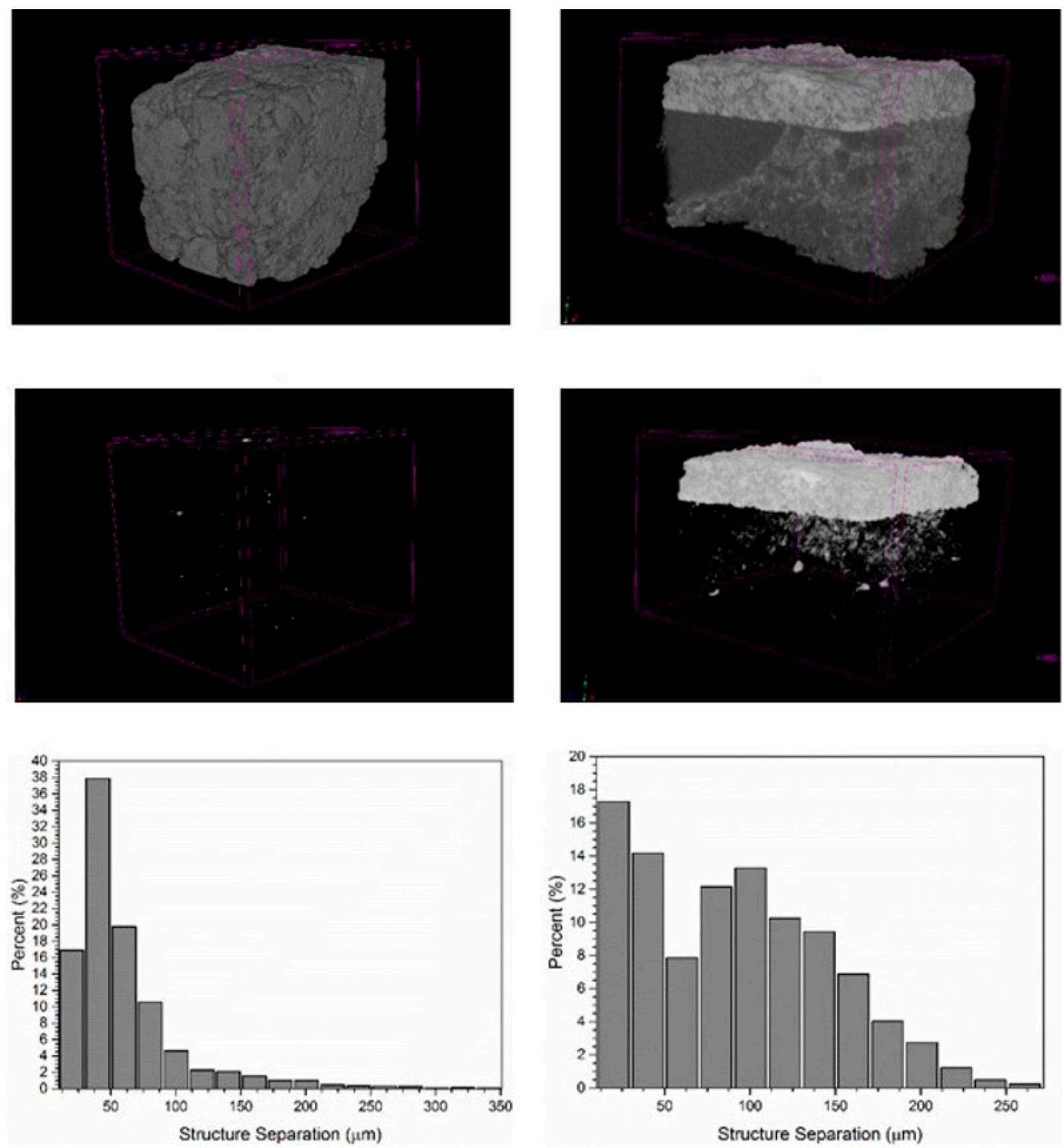

a)

b)

Figure 10. 3D images and pore size distribution of the brick area obtained by micro-CT of composition: (a) A-1 and (b) A-3 after the sandwich coating test.

The pore size distribution histogram shows that A-3 presented broader distribution with pore size smaller than $250 \mu \mathrm{m}$, whereas for A-1, a narrow distribution is observed, with most of the pores below $100 \mu \mathrm{m}$, but more concentrated at the order of $25-50 \mu \mathrm{m}$. The total porosity was calculated at $20.4 \%$ for A-1, with an average pore size of $62.2 \mu \mathrm{m}$, whereas A-3 presented 19.7\% total porosity and $90.9 \mu \mathrm{m}$ average pore size. Although they present similar total porosity, the higher average pore size of A-3 implies greater permeability, which seems to be essential to adhere coating to magnesia-spinel bricks. 


\section{Conclusions}

This investigation was able to enhance the adherence ability of coating on magnesiaspinel refractory bricks varying the additives and firing temperature used. During the work, it was possible to confirm, with the selected clinker composition, that the coating formation and adherence on the brick surface depend on physical and chemical interaction between the clinker and the brick.

The physical interaction was facilitated when the permeability of the refractory was elevated and when it presented good sintering degree, mainly due to the use of high firing temperature. These characteristics demonstrated great importance to improve coatability, since high permeability promotes clinker infiltration, whereas suitable sintering degree promotes the contact of refractory particles with the clinker phases.

For chemical interaction, it has been demonstrated that the formation of liquid phase is essential to adhere coating. In this way, the addition of $2 \mathrm{wt} . \%$ of limestone was the most efficient to improve the coating strength from $0 \mathrm{MPa}$ to $3 \mathrm{MPa}$ of a typical magnesia-spinel brick. However, this addition resulted in a drop in hot modulus of rupture at $1200{ }^{\circ} \mathrm{C}$ and $1485^{\circ} \mathrm{C}$ because of the presence of $C_{12} \mathrm{~A}_{7}$ and $\mathrm{Q}$ phase. Thus, alternative compositions which combine good adherence and hot properties would be preferably those with higher firing temperature and maintaining a high level of purity of the refractory.

Therefore, it can be said that it is possible to improve the coatability of magnesia-spinel bricks through the design of their composition.

Author Contributions: Conceptualization, G.R.C.P., G.E.G. and V.d.F.C.L.; methodology, G.R.C.P. and G.E.G.; validation, G.R.C.P. and G.E.G.; investigation, G.R.C.P.; writing-original draft preparation, G.R.C.P.; writing - review and editing, G.R.C.P., G.E.G. and V.d.F.C.L.; visualization, G.R.C.P.; supervision, G.E.G. and V.d.F.C.L.; project administration, G.R.C.P. and V.d.F.C.L. All authors have read and agreed to the published version of the manuscript.

Funding: This research received financial support of Conselho Nacional de Desenvolvimento Científico e Tecnológico, CNPq, grant number 306291/2018-5 to Vanessa Lins.

Institutional Review Board Statement: Not applicable.

Informed Consent Statement: Not applicable.

Acknowledgments: The authors are grateful to RHI Magnesita, for providing the infrastructure for this work, and CNPq. We thank Breno Barrioni and Marivalda Pereira for performing micro-CT analysis, and Lourdes Pinto and Diana Escobar for SEM analysis.

Conflicts of Interest: The authors declare no conflict of interest.

\section{References}

1. Griffin, D.; Knauss, R. New developments in fired doloma bricks used in rotary cement kilns. In Proceedings of the Unified International Technical Conference on Refractories (UNITECR), Salvador, Brazil, 13-16 October 2009.

2. Guo, Z.; Palco, S.; Rigaud, M. Bonding of Cement Clinker onto Doloma-Based Refractories. J. Am. Ceram. Soc. 2005, 88, 1481-1487. [CrossRef]

3. Guo, Z.; Palco, S.; Rigaud, M. Reaction Characteristics of Magnesia-Spinel Refractories with Cement Clinker. Int. J. Appl. Ceram. Technol. 2005, 2, 327-335. [CrossRef]

4. Sengupta, P. Refractories for the Cement Industry; Springer: Cham, Switzerland, 2020; pp. 185-192.

5. $\quad$ Brito, C.; Reis, E.M. Doloma brick benefits. Int. Cem. Rev. 2015, 99-102.

6. Rigaud, M.; Guo, Z.; Palco, S. Coating formation on basic bricks in rotary cement kilns. In Proceedings of the Asociación Latinoamericana de Fabricante de Refractarios (ALAFAR), Pucón, Chile, 5-7 December 2000.

7. Tokunaga, K.; Kozuka, H.; Honda, T.; Tanemura, F. Further improvement in high temperature strength, coating adherence, and corrosion resistance of magnesia-spinel bricks for rotary cement kiln. In Proceedings of the Unified International Technical Conference on Refractories (UNITECR), Aachen, Germany, 23-26 September 1991.

8. Kozuka, H.; Kjita, Y.; Tokunaga, K.; Sakakbara, K.; Ohta, S. Further improvement of MgO-CaO-ZrO 2 bricks for burning zone of rotary cement kiln. In Proceedings of the Unified International Technical Conference on Refractories (UNITECR), Kyoto, Japan, 19-22 November 1995.

9. Ukawa, S.; Arai, M.; Inoue, S.; Azuma, T.; Sakai, R.; Shikama, S. The application of chrome-free bricks with improved coating adhesion for cement rotary kilns. J. Tech. Assoc. Refract. 2009, 29, 122-128. 
10. Chen, J.; Yan, M.; Su, J.; Li, B.; Sun, J. The kiln coating formation mechanism of $\mathrm{MgO}^{-} \mathrm{FeAl}_{2} \mathrm{O}_{4}$ brick. Ceram. Int. 2016, 42, 569-575. [CrossRef]

11. Meng, W.; Ma, C.; Ge, T.; Zhong, X. Effect of zircon addition on the physical properties and coatability adherence of MgO2CaO. $\mathrm{SiO}_{2}-3 \mathrm{CaO} . \mathrm{SiO}_{2}$ refractory materials. Ceram. Int. 2016, 42, 9032-9037. [CrossRef]

12. Lin, X.; Yan, W.; Ma, S.; Chen, Q.; Li, N.; Han, B.; Wei, Y. Corrosion and adherence properties of cement clinker on porous periclase-spinel refractory aggregates with varying spinel content. Ceram. Int. 2017, 43, 4984-4991. [CrossRef]

13. Pacheco, G.; Gonçalves, G.E.; Lins, V. Qualitative and Quantitative coating tests: A comparison in Magnesia-Spinel Refractory Bricks. Ceramics 2020, 3, 144-154. [CrossRef]

14. Zhao, M. Quantitative Control of $\mathrm{C}_{2}$ S Crystal Transformation. Appl. Mech. Mat. 2012, 121, 311-315. [CrossRef]

15. Wajdowicz, A.; Gonçalves, G.E.; Pacheco, G.R.C.; Pinilla, J.; Oliveira, M.G.; Brito, M.A.M. Magnesia-spinel brick: A Thermal Overload Case. In Proceedings of the 54th International Colloquium on Refractories, Aachen, Germany, 19-20 October 2011.

16. Guotian, Y.; Yanqing, X. $\mathrm{ZrO}_{2}$ containing Refractories for Cement Rotary Kilns. China's Refract. 2002, 11, 13-16.

17. Landis, E.N.; Keane, D.T. X-ray microtomography. Mat. Charact. 2010, 61, 1305-1316. [CrossRef]

18. Hubalkova, J.; Silva, W.M.; Aneziris, C.G. X-ray computed tomography as a tool for investigation of refractories. In Proceedings of the 53rd International Colloquium on Refractories, Aachen, Germany, 8-9 September 2010. 